https://nv.nltu.edu.ua

https://doi.org/10.15421/40290508

Article received 08.05.2019 p.

Article accepted 30.05.2019 p.

$@ \bowtie$ Correspondence author

N. Ye. Horbenko

УДК 582.683.2:581.524.13:[58.069.029](477-25)

nata.horbenko@gmail.com

Н. Я. Левчик', Д. Б. Рахметов ${ }^{1}$, А. В. Любінська ${ }^{1}$, Н. Є. Горбенко ${ }^{2}$

${ }^{1}$ Наиіональний ботанічний сад ім. М. М. Гришка, НАН України, м. Київ, Украӥна

${ }^{2}$ Національний лісотехнічний університет України, м. Львів, Україна

\title{
АЛЕЛОПАТИЧНИЙ ПОТЕНЦІАЛ РОСЛИН РОДУ CRAMВЕ L. (ВRASSICACEAE BURNETT) КОЛЕКЦІЇ НАЦІОНАЛЬНОГО БОТАНІЧНОГО САДУ ІМЕНІ М. М. ГРИШКА НАН УКРАЇНИ
}

Здійснено докладний літературний огляд, висвітлено досвід дослідників минулого та сьогодення і зроблено висновки щодо результатів досліджень рослин роду Crambe L. та сформульовано проблематику досліджень. Подано результати комплексного дослідження алелопатичної активності водорозчинних біологічно активних сполук вегетативної частини, насіння та ризосферних виділень рослин роду Crambe L., кількісний вміст та співвідношення яких перебуває у певній динаміці протягом вегетації. Встановлено, що завдяки їм рослини здійснюють алелопатичний вплив (стимуляційний або інгібуючий) на навколишні вищі рослини і сила дії змінюється залежно від фаз вегетації та тест-об'єктів. Виявлено, що максимальний рівень інгібування біологічно активними сполуками вегетативної частини, плодів та насіння досліджуваних видів Crambe, незалежно від тест-об'єктів та фази вегетації рослин, відбувається за умови, що концентрація витяжки становить 1:10. Найсильніша стимуляція відбувається за умови, що концентрація витяжки становить 1:100. 3'ясовано, що в першій половині вегетації для біологічно активних сполук надземної маси характерне істотне інгібування розвитку тест-рослин. У другій половині вегетації гальмівна та пригнічувальна дія дещо послаблюється. 3 огляду на це, сформульовано стратегію рослин цього роду до виживання та поширення у ценозах.

Ключові слова: Crambe; алелопатична дія; стимулювання; пригнічення; біологічно активні сполуки; тест-рослини; надземна частина; плоди; насіння; ризосферний грунт.

Вступ. Важливою і благородною місією людства загалом і ботанічних садів зокрема, на наш розсуд, $є$ збереження та збагачення природного рослинного фонду планети, особливо рідкісних та рослин, що зникають. До переліку таких рослин належать представники роду Crambe L, яких занесено до Червоної книги України в категорії вразливі та зникаючі види (Dudchenko, Kozyakov \& Kryvenko, 1989; Red Book, 2019).

Crambe L. - рід багаторічних та однорічних рослин родини Brassicaceae, який налічує близько 30 видів, 3 них в Україні зростає вісім. (Nechytaylo \& Kucheryava, 2005). Надземна частина рослин гладенька або опушена простими волосками, з великими розлогими листками i численними білими квітками, зібраними у великі волотевидні суцвіття. Плід горішок, що складається 3 двох члеників, 3 яких верхній - кулястий, однонасінний, нижній - короткий неплідний (Nechytaylo \& Kucheryava, 2005; Lypa, 1964).

Катран належить до овочевих культур завдяки стрижневому білому товстому м'ясистому соковитому кореню, що нагадує хрін, та має високі бактерицидні властивості (Mykhaylova \& Biriuliova, 2013). Окрім цього, корінь катрана багатий на вітаміни та мікроелементи, а гострий смак надають йому ефірні олії. Зокрема, корені катрану татарського містять крохмаль, гірчичну олію, калій, фосфор, білок, до 12 \% цукрів та фітонциди. У пагонах рослини виявлено амінокислоти валін і гістидин, кальцій та фолієву кислоту. Окрім цього, в насінні міститься від 14 до 40 \% жирної олії, багатої на олеїнові, стеаринові, линолеві та линоленові кислоти, тому деякі види катрану культивують як жироолійні та силосні рослини. 3 молодих весняних листків і пагонів певних видів готують салати, вирощують як овочеві рослини (Dudchenko \& Pushkariova, 1989).

Важливо зазначити, що рослини Crambe належать i до лікарських культур, хоча не входять до фармакопейних списків офіційної медицини, проте їх застосовують у народній медицині. Зокрема, тертий хрін цілком

Інформація про авторів:

Левчик Наталія Яківна, канд. біол. наук, наук. співробітник, відділ культурної флори.

Email: levchyk.n@ukr.net; https://orcid.org/0000-0001-8668-8763

Рахметов Джамал Бахлул-огли, д-р с.-г. наук, професор, завідувач відділу культурної флори.

Email: jamal_r@bigmir.net; https://orcid.org/0000-0001-7260-3263

Любінська Алла Василівна, провідний інженер, відділ культурної флори.

Email: alla@ukr.net; https://orcid.org/0000-0002-1873-8252

Горбенко Наталія Євгенівна, канд. с.-г. наук, доцент, кафедра ботаніки деревинознавства та недеревних культур.

Email: nata.horbenko@gmail.com; https://orcid.org/0000-0002-6053-6582

Цитування за ДСтУ: Левчик Н. Я., Рахметов Д. Б., Любінська А. В., Горбенко Н. Є. Алелопатичний потенціал рослин роду Сraтbe L. (Brassicaceae Burnett) колекції Національного ботанічного саду імені М. М. Гришка НАН України. Науковий вісник НЛтУ України. 2019, т. 29, № 5. С. 40-46.

Citation APA: Levchyk, N. Ya., Rahmetov, D. B., Liubinska, A. V., \& Horbenko, N. Ye. (2019). The alelopathic potential of Crambe L. Plants (Brassicaceae Burnett) at collection of M. M. Hryshko National botanical garden, NAS of Ukraine. Scientific Bulletin of UNFU, 29(5), 40-46. https://doi.org/10.15421/40290508 
може замінити гірчичники. Завдяки вітаміно-мінеральному складу та біологічно активним сполукам, що входять як до надземної маси, так і до кореневища, рослини мають протицинготні, фітонцидні, антибіотичні та травні властивості, та є онкопротекторами захворювань травної системи.

Завдяки декоративним властивостям рослини різних видів Crambe можна вирощувати на клумбах, кам'янистих гірках, газонах. Добрі медоноси. Легко розмножуються насінням.

Отже, представники роду Crambe мають великий господарський і промисловий потенціал, оскільки їх використовують як технічні, харчові та декоративні рослини. Дослідження корисних властивостей та розширення сфери вжитку рослинної сировини катранів наразі актуальне і промислово доцільне. Колекція рослин відділу культурної флори Національного ботанічного саду ім. М. М. Гришка НАНУ становить 8 видів цього роду Crambe (рис. 1).

Проте залишається актуальною також проблема взаємовпливу та взаємодії нових нетрадиційних рослин Crambe 3 представниками традиційної культурної флори України, їх вплив на стан грунту та роль у процесах, що призводять до грунтовтоми. Відомо, що завдяки безперервному виділенню рослинами в зовнішнє середовище різноманітних органічних сполук, навколо них створюється біохімічна аура або захисна сфера $з$ активних речовин, що негативно або навпаки сприятливо діють на навколишні рослини. Так, М. Evenari (Evenari, 1949) одним із перших виявив значне поширення потужних інгібіторів проростання у різних видів хрестоцвітих. Основними сполуками, які володіють інгібуючою дією, $€$ гірчичні олії.

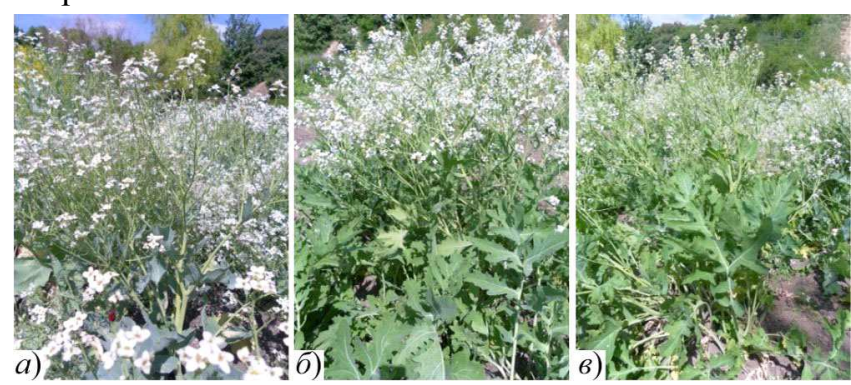

Рис. 1. Представники роду Crambe: $a$ ) - C. pontica; $b)-C$. coctebelica; $c)-$ C. steveniana в колекції НБС ім. М. М. Гришка

За силою алелопатичного впливу рослини Crambe, згідно 3 поділом А. М. Гродзінського (Grodzinskiy, 1973), належать до групи алелопатично дуже активних рослин, які розмножуються тільки насінням, та використовують алелопатичний механізм для свого вторгнення в густі трав'янисті угруповання. Зокрема, всі органи катрана татарського Crambe tatarica Sebeok, на його думку, містять біологічно активні сполуки (Grodzinskiy \& Gorobetz, 1989).

Особливу активність, за дослідженнями вченого, мають плоди катрану татарського та інших видів цього роду. Оскільки насінна продуктивність рослин надзви-

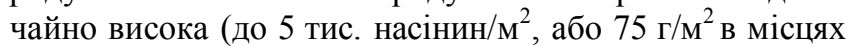
зростання), варто досліджувати та враховувати це під час культивування. Велика кількість насіння під час проростання виявляється потужним джерелом алелопатичної активності та здійснює гальмівну дію на насіння того ж або інших видів рослин (Hrodzinskiy, Kuznietzova \& Musatenko, 1960).
Порівнюючи плоди катрану татарського, зібраних в умовах природного місцезростання в Хомутівському степу, з плодами катрану, який кілька генерацій вирощувався в ботанічному саду, доведено, що під час введення рослин у культуру їхня алелопатична активність знижується (табл. 1).

Табл. 1. Дія водних витяжок 1:10 з плодів катрану татарського Crambe tatarica Sebeok різного походження на проростання насіння тест-культур (\% до контролю)*

\begin{tabular}{|c|c|c|}
\hline Тест-об'єкт & $\begin{array}{c}\text { Плоди природного } \\
\text { угруповання }\end{array}$ & $\begin{array}{c}\text { Плоди в посіві } \\
\text { НБС }\end{array}$ \\
\hline Редиска & 29,4 & 54,3 \\
\hline Пшениця озима & 51,0 & 65,0 \\
\hline Салат-латук & 54,2 & 65,5 \\
\hline
\end{tabular}

Примітка: за А. М. Гродзінським (Grodzinskiy, 1965)

Таке зниження алелопатичної активності в культивованих рослин, порівняно 3 їх дикими прототипами, відбувається внаслідок несвідомого добору рослин на скоростиглість і на "нестомлення" грунту. Оскільки більш скоростиглі сорти рослин зазвичай містять у своїх тканинах менше гальмувачів росту та коротший вегетаційний період, тому вони є менш активні в алелопатичному відношенні. Очевидно, що під час інтродукції та повторного вирощування у природі відбирались форми 3 меншим вмістом гальмувачів у плодах, оскільки вони давали більш ранні та дружні сходи i, як наслідок, більш ранній та багатший урожай (Grodzinskiy \& Gorobetz, 1989; Grodzinskiy, 1973).

Поряд із терміном "гальмувачі", А. М. Гродзінський, за прикладом Г. Грюмера, часто вживає термін "коліни", хоча їхня токсична дія не ідентична і залежить від концентрації та інших чинників. Коліни - це органічні речовини, які утворюються у процесі метаболізму вищих рослин та мікроорганізмів, виділяються у довкілля і впливають на ріст інших рослин, селекціонують мікрофлору (Yurchak, 2005).

Механізм дії колінів відбувається на трьох рівнях: клітинному (біохімічні механізми), організмовому (фізіологічні механізми) і фітоценотичному (екологічні або алелопатичні механізми) (Grodzinskiy, 1973). Загалом коліни діють неспецифічно, тобто високі дози або тривалі впливи спричиняють пригнічення, малі концентрації і короткочасні впливи - стимулюють (Grodzinskiy, 1973).

Екзометаболіти вищих рослин передусім діють на стан клітинних мембран, змінюючи їхні проникність (Roshchina, 1974) та активність мембранопов'язаних ферментних систем (Rais, 1978; Roshchina, 1974). Загалом зниження ростових процесів може зумовлюватися не тільки прямою дією на процеси ділення і диференціації клітин, а й загальмуванням таких процесів, як фотосинтез, дихання, надходження води і поживних речовин, пересування пластичних речовин до точок росту (Grodzinskiy, 1973).

Характерним для багаторічних рослин способом алелопатичного впливу є створення власного алелопатичного поля. До складу цього поля входять фітоактивні речовини, що містяться в опаді та підстилці, та вилуговуються 3 листків дощами. Окрім цього, леткі та водорозчинні сполуки виділяються листками і коренями та зосереджуються переважно у верхньому шарі грунту. Тут $\epsilon$ й основна мікрофлора, яка створює або руйнує коліни. Увесь цей мінливий комплекс активних речовин утворює алелопатичне поле рослини (Grodzinskiy, 1973). 
Отже, кореневі виділення є основою живлення ризосферної і грунтової мікрофлори, беруть участь в обміні метаболітами між рослинами, а тому відіграють дуже важливу роль у хімічній взаємодії рослин (Grodzinskiy, 1973).

Гальмувачі насіння та плодів. Окрім цього, для алелопатичної дії та утворення мікроасоціації дуже важливо, щоб гальмівна речовина 3 плодів та насіння була стійкою, не поглиналася безплідно грунтом і зберігала свою активність досить тривало. Зокрема, досліджений гальмувач проростання із плодів катрану татарського за аеробних умов компостування зберігав активність протягом шести місяців. Він незначно поглинався грунтами з природних місць поширення катрану. В анаеробних умовах гальмувач повністю втрачав свою активність через 12-15 днів (Grodzinskiy, 1973).

Серед гальмувачів насіння ідентифіковано ди- та трикарбонові органічні кислоти, амінокислоти, ненасичені ароматичні кислоти - кавова, корична та ферулова; альдегіди - цитраль, коричний альдегід, саліциловий альдегід, бензальдегід; ненасичені лактони - кумарин, скополетин, протеанемонін, парасорбінова кислота, аміак, флавонові пігменти, дегідрооцтова кислота, дезацетин та фталід, індолілоцтова кислота та ін. (Grodzinskiy, 1965). Гальмувачі у плодах та насінні частково містяться у зв'язаній формі. Значну кількість активних сполук можна вивільнити за допомогою гідролізу. Зокрема, у плодів катрану татарського екстрагування гальмувачів виконували способом настоювання наважки сухих плодиків у 10-кратній кількості розчинника протягом доби за кімнатної температури.

Табл. 2. Екстрагування гальмувачів із плодів катрану татарського Crambe tataria Sebeok. кислим та лужним розчинниками (вміст гальмувачів в УЕК)*

\begin{tabular}{|c|c|c|}
\hline Розчинник & Перша витяжка & $\begin{array}{c}\text { Повторна витяжка } \\
\text { (водна) }\end{array}$ \\
\hline Вода & 250 & 183 \\
\hline $20 \%$ оцтова кислота & 1100 & 585 \\
\hline $20 \%$ аміак & 202 & 78 \\
\hline
\end{tabular}

Примітка: за А. М. Гродзінським (Grodzinskiy, 1965)

Біологічна функція гальмувачів у плодах полягає у підтриманні насіння у стані спокою та в гальмуванні росту навколишньої рослинності.

Важливо зазначити, що тіоглюкозид глюкобрасицин (містить сірку), який трапляється у представників хрестоцвітих роду Brassicaceae, володіє помітною фітотоксичною активністю і $є$ для цієї родини специфічним захисним механізмом. Цікаво, що він діє не на всі рослини та виступає умовно потенційним інгібітором, оскільки він нешкідливий для рослин, які нездатні його гідролізувати або, навпаки, гідролізують до безпечних продуктів (капуста, редька).

Пшениця ж розкладає клюкобрасицин наполовину до індолацетонітрилу, тому сильно страждає від дії цього глюкозиду (Grodzinskiy, 1965; Kutáček, 1964). Алелопатична дія глюкобрасицину полягає в тому, що він попадає в грунт з післяжнивними залишками капусти, редису, катрана, рапсу та інших хрестоцвітих та може істотно впливати на подальші культури завдяки вивільненню внаслідок специфічного ферментативного розщеплення великої кількості гальмівних сполук (Kutáček, 1964). Ця речовина токсична для деяких різновидів шкідників. Окрім цього, глюкобрасицин має потужну протипухлинну дію і особливо ефективний проти раку молочної залози (Galletti et al., 2014).
Гальмувачі проростання у плодах, насінні та в екстрактах амінокислотної природи також мають істотний алелопатичний вплив (Blagoveshchenskiy, 1953; Blagoveshchenskiy,1957). Окрім цього, наявність амінокислот та подібних сполук в екстрактах має вищий ступінь кореляції з їх гальмівною активністю, ніж це було виявлено зокрема для дубильних сполук (Grodzinskiy, 1965). Дослідження іранських вчених Seyed Mehdi Razavi показало, що композиція ефірних олій рослин C.orientalis має незначний алелопатичний ефект на салаті латук, проте високий рівень цитотоксичної активності з протиканцерогенним ефектом (Razavi, Nejad-Ebrahimi, 2009), що має надзвичайно вагоме практичне використання у сфері охорони здоров'я.

Метою наших досліджень було виявлення та встановлення сили і характеру алелопатичної активності водорозчинних сполук надземної частини та кореневих виділень рослин роду Crambe колекції відділу культурної флори Національного ботанічного саду ім. М. М. Гришка НАН України.

Матеріали і методи дослідження. Об'єктом дослідження були три види роду Crambe: C. pontica Steven, C. koktebelica Junge та C. steveniana Rupr. Алелопатичну активність надземної маси та прикореневого грунту досліджували за методикою рослинних біотестів А. М. Гродзінського (Grodzinskiy, Golovko \& Gorobetz, 1987), використовуючи як тестові культури огірок $C u$ cumis sativus сорту "Конкурент", редис червоний з білим кінчиком Raphanus sativus Pers. та амарант Amarantus paniculatus. Для біотестів готували водні витяжки 3 листків та плодів катрану Crambe у концентраціях 1:10, 1:50 та 1:100.

Результати дослідження та дискусія. 3 досліджень видно, що надземна частина досліджуваних видів роду Crambe містить, а коренева система виділяє в шари прикореневого грунту біологічно активні сполуки. Алелопатична активність цих сполук на проростки тесткультур проявляється як в істотному інгібуванні, так і у стимулюванні та змінюється в певній динаміці протягом вегетаційного періоду.

Вплив водорозчинних сполук надземної частини рослин Crambe. Максимальний рівень інгібування біологічно активними сполуками листків досліджуваних видів Crambe процесів росту всіх, без винятку, тесткультур спостерігали за концентрації витяжки з листків 1:10, незалежно від фаз вегетації рослин. Найсильніше інгібування зафіксували у першій половині вегетації рослин фазу відростання - цвітіння на проростках амаранту $(35,4 \%)$ під дією C. pontica, дещо меншу - на проростках огірка $(42,4 \%)$ під дією C. koktebelica та редьки (44,1 \%) під дією C. pontica. Наприкінець вегетації максимальна інгібуюча дія становила 48,38 \% на проростках редису під дією C. koktebelica, дещо менша (54,25 \%) на редисі під дією C. pontica, 73,2 \% - на проростках амаранту та 74,88 \% - на проростках огірка під дією C. pontica.

У першій половині вегетації катрану відзначили загальну тенденцію до істотного гальмування проростків амаранту та огірка водорозчинними сполуками Crambe. На проростках редису зафіксували істотне стимулювання водними розчинами $C$. koktebelica 3 показником $117,20 \%$ за концентрації розчину 1:50 та $142,70 \%$ - за концентрації 1:100. Варто зазначити, що на проростки огірка та амаранту під дією рослин C. steveniana, $C$. 
koktebelica, C. pontica і редису під дією C. steveniana та C. pontica здійснювалось тільки інгібування, дія якого зросла під час збільшення концентрації розчину в прямій пропорційності. C. koktebelica здійснював стимуляційну дію на проростки редису. Ця дія збільшувалась із зменшенням концентрації в прямій пропорційності (рис. 2).
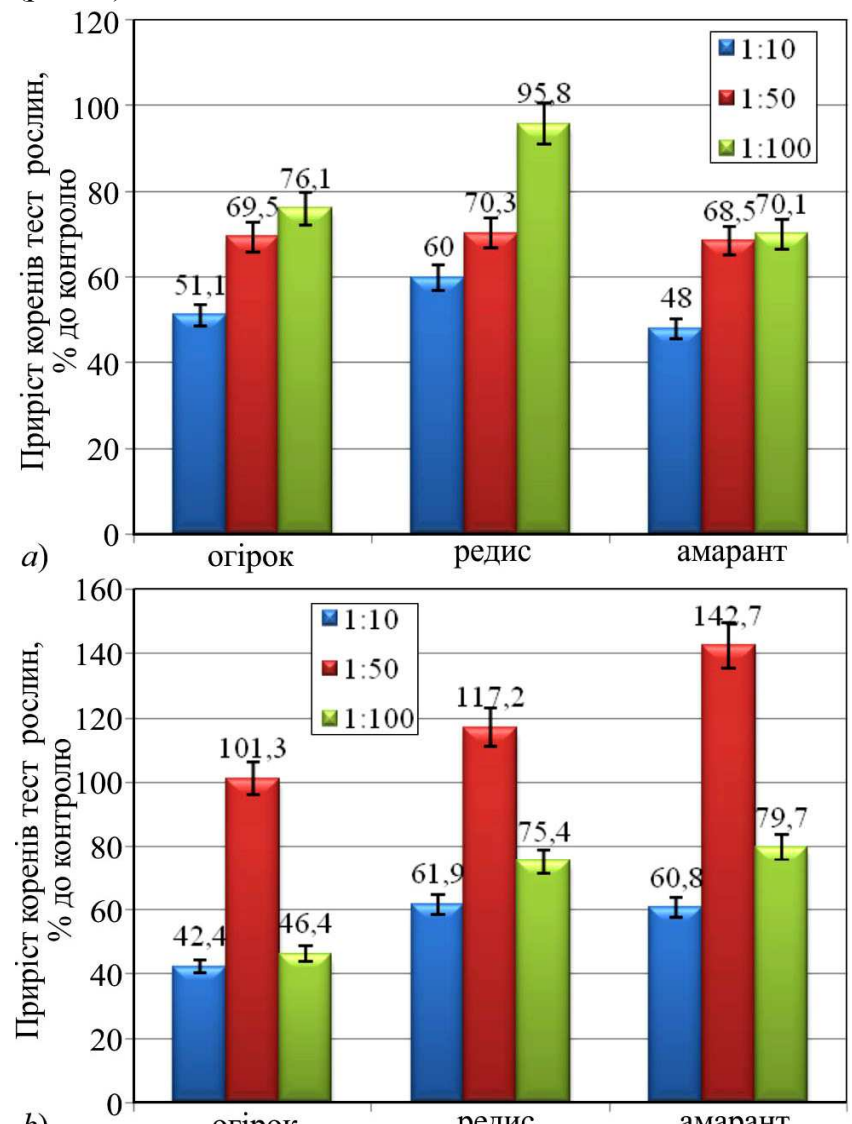

b)

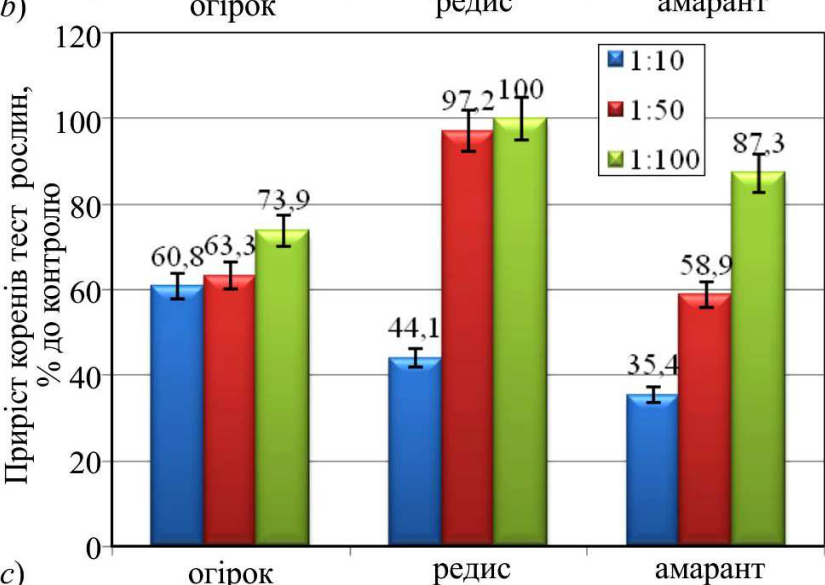

Рис. 2. Алелопатична активність водних витяжок рослин роду Crambe залежно від концентрації, фаза відростання - цвітіння (\% до контролю): a) C. steveniana; в) C. koktebelica; c) C. pontica

Наприкінці вегетаційного періоду (рис. 3) характер дії біологічно активних сполук досліджуваних рослин Crambe значно змінився, зокрема 3 інгібування на значне стимулювання. Однак збереглась тенденція до істотного гальмування насіння огірка витяжками $C$. steveniana та $C$. pontica i, як виняток, незначна стимуляційна дія C. koktebelica в концентраціях 1:50 та 1:100.

Відзначено, що розчин у концентрації $1: 10 \epsilon$ найбільш алелопатично активним із пригнічувальною дією, незалежно від фази вегетації рослин та виду обраних тест-культур.

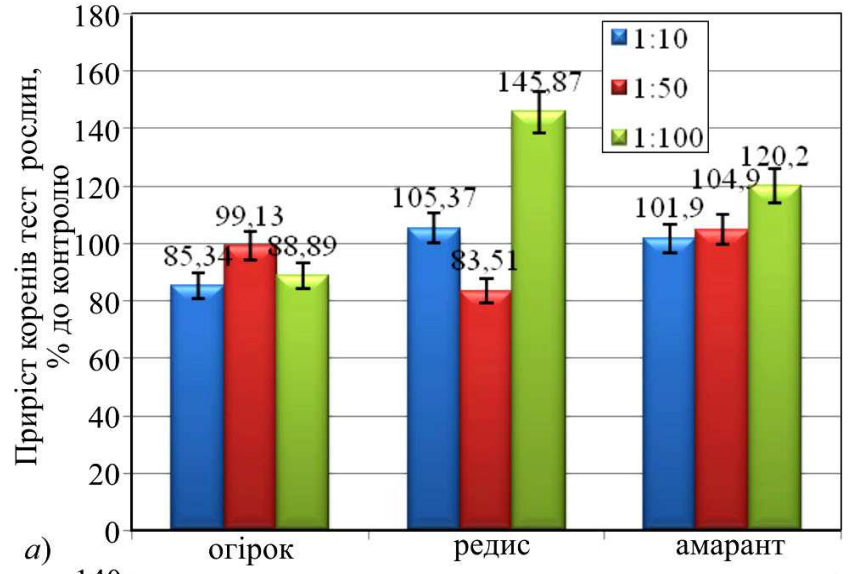

a)

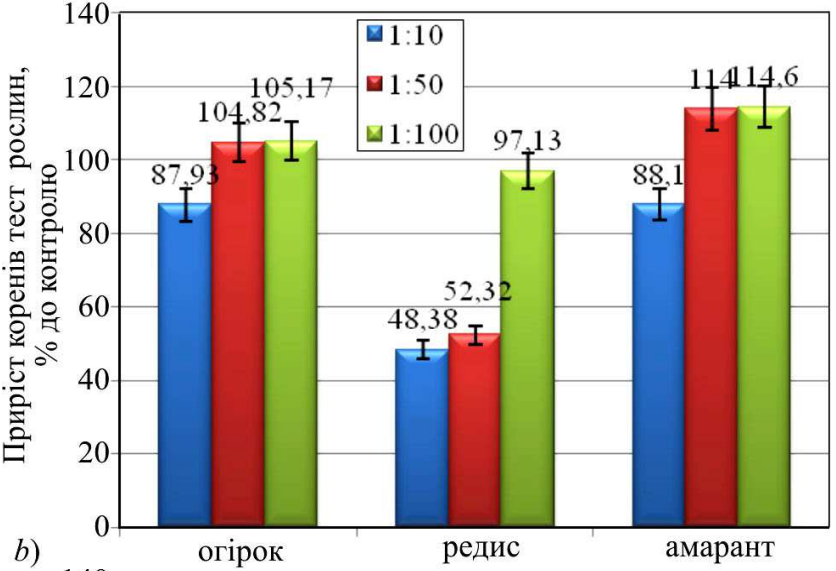

b)

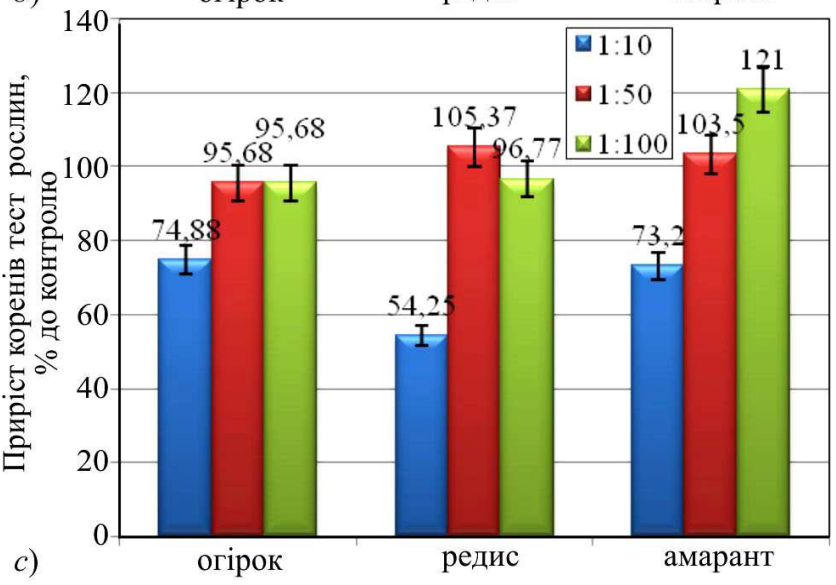

Рис. 3. Алелопатична активність водних витяжок рослин видів роду Crambe залежно від концентрації, фаза кінець вегетації (\% до контролю): a) C. steveniana; в) C. koktebelica; c) C. pontica

Виявлено, що найбільше стимулювання на певну тест-культуру в цей період відбувається саме під час концентрації діючого розчину 1:100. Наприклад, на проростках редису максимальний стимуляційний ефект $145,87 \%$ зафіксовано під час дії C. steveniana, дещо нижче - 121,00\% та 120,20 \% - на проростках амаранту під час дії C. pontica та відповідно C. steveniana.

Для проростків амаранту характерною $є$ закономірність: незалежно від виду Crambe стимуляційна дія біологічно активних сполук екстракту збільшується із зменшенням його концентрації. Найбільш чутливим тест-об'єктом до стимуляційної дії водорозчинних компонентів надземної маси рослин Crambe став редис, середньочутливим - амарант, найменш чутливим - огірок. Варто зазначити, що характерна стимуляційна дія C. koktebelica на проростки редису в першій половині вегетації змінилась у другій ії половині істотним інгібуванням, незалежно від концентрацій екстрактів Crambe. 
Алелопатична активність насіння та плодів Crambe. Біохімічний вміст насінини свідчить про наявність біологічно активних сполук, які утримують насіння у стані спокою та тією чи іншою мірою є гальмувачами навколишніх рослин, забезпечуючи звільнення життєвого простору у фітоценозах, допомагають розширенню ареалу рослин та боротьбі з конкурентами за місце на певній території, за вологу, сонце. Ці гальмувачі є водорозчинними, оскільки виділяються із плодів та насіння рослин під час набухання у воді. Дуже важливим моментом $\epsilon$ факт опадання плодиків не поодиноко, а групами, як це часто відбувається у катрана, створюючи в такий спосіб невеликий масовий осередок нового компонента ценозу (Grodzinskiy, 1965). Тому окремо опале насіння або плід не може викликати відчутного алелопатичного ефекту (Grodzinskiy, 1965). Цікаво, що розподілення гальмувачів між частинами плоду зазвичай таке: найменша кількість гальмувачів у насінні, за мірою віддалення від нього кількість гальмуючих сполук зростає (Grodzinskiy, 1965).

Для встановлення ролі гальмувачів у плодах та насінні важливо з'ясувати життєву форму рослин та яким чином відбувається поширення насіння навколо. Катран належить до рослин із життєвою формою перекотиполе, що полягає в розповсюдженні насіння за допомогою вітру. Зазвичай тварини не поїдаються ці рослини внаслідок вмісту в них шкідливих сполук (Aliokhin, 1939). Рослини належать до багаторічників із стрижневим коренем, не здатні до вегетативного розмноження, тому накопичення відмерлих надземних частин, які тварини не поїдають, може стати причиною самопригнічення. Тому можна припустити, що плоди та насіння таких рослин із життєвою формою перекотиполе містять велику кількість гальмувачів. За літературними даними, вміст гальмувачів у плодах та насінні рослин катрану становить 51-1100 в УЕК, що істотно перевищує вміст гальмувачів у рослин, що поширюються за іншими принципами. Зокрема, сосна звичайна 10,5 УЕК, салат-латук 36,5 УЕК, кульбаба звичайна 83,0-128,0 УЕК (Grodzinskiy, 1965). Згідно з отриманими даними, витяжки 3 плодів та насіння досліджуваних видів катрана в концентрації 1:10 здійснюють виключно гальмуючу дію на проростки тест-культур (рис. 4).

Найсильнішу гальмуючу дію 28,09 \% зафіксовано на проростках амаранту сполуками витяжки C. koktebelica. Найсильнішу стимуляційну дію здійснюють сполуки $C$. pontica за умови, що концентрація екстракту буде 1:50 на проростки огірка та 1:100 на проростки редису. Виявлено тенденцію, що розчини в концентрації 1:10 здійснюють інгібуючу дію, натомість розчини в концентрації 1:50 та 1:100 можуть здійснювати як інгібуючу, так і стимуляційну дію, що перебуває в прямій залежності із видом катрана та тест-культурою. Винятком є тільки розчин C. steveniana, який здійснював тільки пригнічувальну дію на проростки амаранту, реакція якого полягала тільки у сповільненні власного росту та розвитку.

Алелопатична активність ризосферного грунту рослин Crambe. Окрім цього, коренева система рослин Crambe впродовж вегетації виділяє в ризосферний грунт біологічно активні сполуки, які здійснюють хімічний вплив на навколишні угруповання рослин. Ці виділення створюють у середовищі фітоценозу певний алелопатичний потенціал, який допомагає рослинам розмножуватися та поширюватися на певній території.
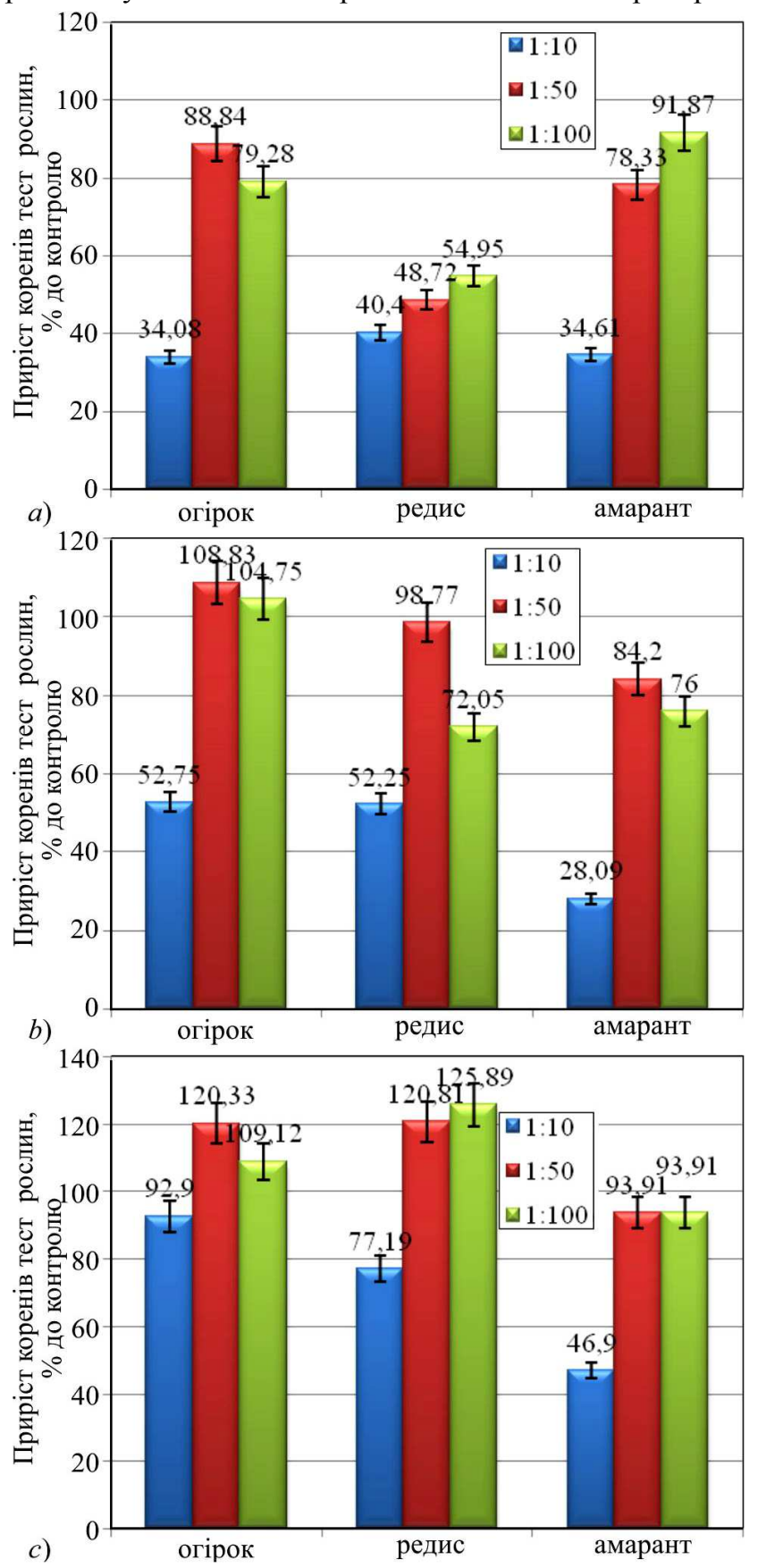

Рис. 4. Алелопатична активність насіння та плодів рослин видів роду Crambe (\% відповідно контролю): a) C. steveniana; в) C. koktebelica; c) C. pontica

Алелопатичну активність досліджуваних рослин зумовлюють не одна певна сполука, а комбінація багатьох сполук, які належать до різних класів. Переважно це низькомолекулярні продукти відносно простої будови, високогідрофільні, що і визначає їхню активну алелопатичну дію (Hrodzinskiy, Kuznietzova \& Musatenko, 1960; Grodzinskiy \& Gorobetz, 1989).

Відомо, що в кореневих виділеннях можуть міститися органічні кислоти, азотисті сполуки, цукри, ферменти, вітаміни, алкалоїди, глюкозиди, антибіотики, природні та синтетичні ростові речовини (Grodzinskiy, 1973). Фізіологічна дія кореневих виділень полягає насамперед у зміні метаболізму коренів акцепторних рослин, у прискоренні чи сповільненні надходження води 
та поживних речовин. Після проникнення в рослини, фізіологічно активні виділення чинять різноманітні впливи на обмін речовин, які проявляються загалом у стимуляції чи пригніченні ростових процесів. А з іншого боку, кореневі виділення значно опосередковано впливають на фізіологію рослини через зміну та формування особливої ризосферної мікрофлори грунту (Grodzinskiy, 1973).
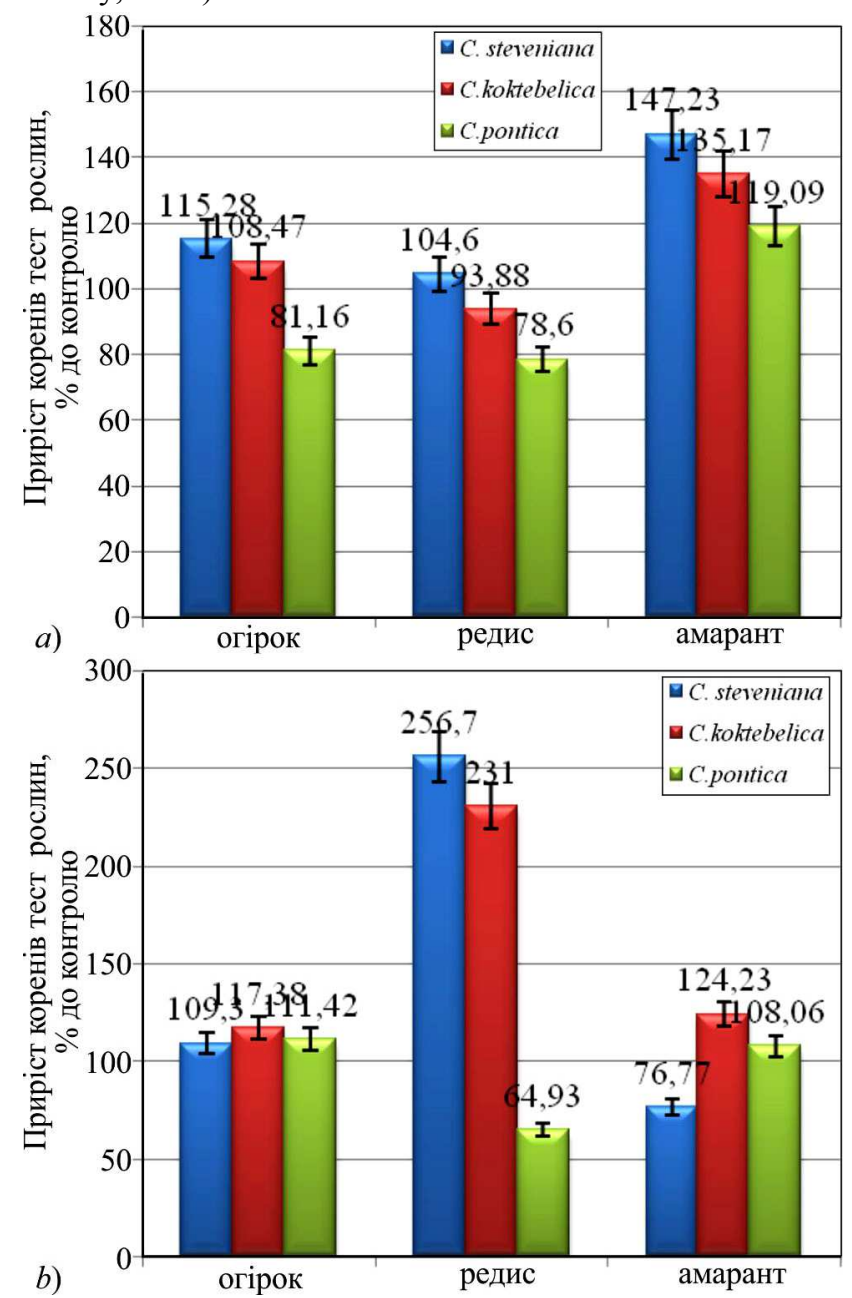

Рис. 5. Алелопатична активність прикореневого грунту рослин видів роду Crambe, фаза плодоношення $(a)$ та фаза кінця вегетації (б) (відносно контролю), \%

Отримані результати свідчать про те, що дія метаболітів досліджуваних рослин, які виділяються коренями в прикореневий грунт, може мати як стимуляційну, так i інгібуючу дію (рис. 5, 6). Важливо зазначити, що характер дії прикореневого грунту досліджуваних рослин Crambe може змінюватись протягом весняно-літньоосіннього періоду з гальмування на стимулювання i навпаки, залежно від фази вегетації рослин катрану та тест-культур. Зокрема, у фазі плодоношення зафіксовано істотну стимуляційну дію грунту трьох досліджуваних видів Crambe: 119,09\% - у C. pontica, 135,17\% - C. koktebelica та 147,23\%-C. steveniana, на проростки амаранту, незначну $108,47 \%-$ у C. koktebelica та $115,28 \%$ - у C. steveniana - на проростки огірка та інгібуючу дію 78,60 \% C. pontica та 81,16 \% C. koktebelicaна проростки редису (див. рис. 5,a).

Найвищою стимуляційною активністю в цей період, незалежно від тест-культури, відрізнився прикореневий грунт C. steveniana, середньою - C. koktebelica, найнижчою - C. pontica (див. рис. 5,a). Окрім цього, із зміною фаз вегетації рослин Crambe характер активності біологічно активних сполук прикореневого грунту також змінюється із гальмування на стимулювання і навпаки. Так, наприкінці вегетації характер впливу кореневих виділень на тест-культури кардинально змінився (див. рис. $5, б)$.

Так, було зафіксовано сильну стимуляційну дію на проростки редису ризосферного грунту C. steveniana 3 показником 256,7\% та C. koktebelica 231,0\%. Окрім цього, C. koktebelica та $C$. pontica здійснювали дещо нижчу, але істотну стимуляційну дію, зокрема 124,23 \% на проростки амаранту та $117,38 \%$ на проростки огірка. Найчутливішим тест-об'єктом відносно стимуляційної дії досліджуваних кореневих виділень рослин видів Crambe виявився редис, середньочутливим - амарант, найменш чутливим - огірок. Найвищою алелопатичною активністю наприкінці вегетації відзначився грунт $C$. steveniana та $C$. koktebelica, найнижчою $-C$. pontica

Висновки. Надземна частина та кореневі виділення рослин роду Crambe містять біологічно активні сполуки, кількісний вміст та співвідношення яких перебуває у певній динаміці протягом вегетації. Завдяки їм рослини здійснюють алелопатичний вплив (стимуляційний або інгібуючий) на навколишні вищі рослини і сила дії змінюється залежно від фаз вегетації та тест-об'єктів.

Встановлено, що в першій половині вегетації для біологічно активних сполук надземної маси $C$. steveniana, C. koktebelica та $C$. pontica характерне істотне інгібування розвитку тест-рослин, за винятком C. koktebelica, витяжка якого у двох концентраціях (1:50 та 1:100) здійснювала істотну стимуляційну дію на проростки редису. У другій половині вегетації гальмівна дія дещо послаблюється, а в деяких випадках проявляється в істотному стимулюванні. C. koktebelica iз істотного стимулювання проростків редису в першій половині вегетації дія змінилась на інгібування, незалежно від концентрації розчинів. Отже, наприкінці вегетації переважає гальмівна дія на проростки огірка, з тенденцією до стимулювання на проростки редису та безперечна icтотна стимуляційна дія на проростки амаранту.

Встановлено, що максимальний рівень інгібування біологічно активними сполуками вегетативної частини досліджуваних видів Crambe, незалежно від тест-об'єктів та фази вегетації рослин, відбувається за умови, що концентрація витяжки становить 1:10. Найсильніше інгібування 35,4 \% здійснює C. pontica на проростки амаранту. Найсильніша стимуляція 145,87 \% на проростках редису відбувається за умови, що концентрація витяжки C. steveniana становить 1:100. У процесі досліджень з'ясовано, що витяжки 3 плодів та насіння досліджуваних видів Crambe в концентрації 1:10 здійснюють тільки гальмівну дію. Найсильніше пригнічення 28,09 \% зафіксовано під час дії витяжки C. koktebelica на проростки амаранту. Найсильніше стимулювання здійснюють сполуки $C$. pontica на проростки огірка за умови, що концентрація екстракту буде 1:50, та на проростки редису за концентрації 1:100.

Виявлено, що біологічно активні сполуки прикореневого грунту досліджуваних рослин здійснюють інгібуючу та стимуляційну дію на тест-рослини. Характер та сила дії залежить від фази вегетації та рослини-акцептора. Найактивнішим стимуляційним впливом на тест-рослини виявився грунт C. steveniana, середнім - 
C. koktebelica, найнижчим - C. pontica. Найбільшу стимуляційну дію зафіксовано на проростках редису у прикореневого грунту C. steveniana $(256,7 \%)$ та C. koktebelica (231,0 \%). Найсильніше пригнічення (64,93 \%)грунтом $C$. pontica на проростки редису. Ідентифікація алелопатично активних сполук рослин роду Crambe та їхнього впливу на фізіолого-біохімічні процеси в навколишніх рослин потребують подальших досліджень.

\section{Перелік використаних джерел}

Aliokhin, V. V. (1939). Some thoughts on the tumbler-field life form. President of the Academy of Sciences of the USSR Acad. V. L. Komarov to the 70th anniversary of the birth and the 43rd anniversary of scientific activity, 97-107. Moscow-Leningrad: Publishing House of the Academy of Sciences of the USSR. [In Russian].

Blagoveshchenskiy, A. V. (1953). The biochemistry of the difficult seed germination. Proceedings of the Main Botanical Garden of the USSR Academy of Sciences, 3(3), 3-57. [In Russian].

Blagoveshchenskiy, A. V. (1957). On the substances that delay seed germination. Bulletin of the Main Botanical Garden of the USSR Academy of Sciences, 9, 54-58. [In Russian].

Dudchenko, L. G., Kozyakov, A. S., \& Kryvenko, V. V. (1989). The aromatic and spicy plants: Manual. Kyiv: Scientific thought, 304 p. [In Russian].

Evenari, M. (1949). Germination inhibitors. The Botanical Review, $15,153-194$.

Galletti, S., Bagatta, M., Branca, F., Argento, S., De Nicola, G. R., Cianchetta, S., Iori, R., \& Paolino Ninfali, P. (2014). Isatis canescens is a rich source of glucobrassicin and other health - promoting compounds. Journal of the Science of Food and Agriculture, 95, 158-164. https://doi.org/10.1002/jsfa.6697

Grodzinskiy, A. M. (1965). The allelopathy intheplantlife and their communities. Kyiv: Scientific thought, 200 p. [In Russian].

Grodzinskiy, A. M. (1973). The fundamentals of chemical interaction of plants. Kyiv: Scientific thought, 205 p. [In Ukrainian].

Grodzinskiy, A. M., \& Gorobetz, S. A. (1989). The allelopathic active substances of the Russian sea kale fruits. Themethodological problems of the allelopathy: scientific works of the Ukrainian SSR Aca-

demy of Science. CRBG, 104-110. Kyiv: Scientific thought. [In Russian].

Grodzinskiy, A. M., Golovko, E. A., \& Gorobetz, S. A. (1987). Theexperimental allelopathy. Kyiv: Scientific thought, 236 p. [In Russian].

Hrodzinskiy, A. M., Kuznietzova, H. O., \& Musatenko, L. I. (1960). The braking germination in the fruits of the Russian sea kale Crambe tatarica Sebeok. Ukrainian botanical journal, 17(1), 29-39. [In Ukrainian].

Kutáček, M. (1964). Glucobrassicin, a potential inhibitor of unusual type affecting the germination and growth of plants; Mechanism of its action. Biologia Plantarum, 6(2), 88-98. https://doi.org/10.1007/BF02926662

Lypa, O. L. (1964). Vascular plant systematics. Manual, (pp. $227-$ 228). Kyiv: Radianska shkola. [In Ukrainian].

Mykhaylova, O. A., \& Biriuliova, E. G. (2013). The pecualirities of the anatomical structure of the vegetative organs of some protected species of the genus Crambe L. Bulletin of the State Nikitsky Botanical Garden, 108, 83-88. [In Russian].

Nechytaylo, V. A., \& Kucheryava, L. F. (2005). Botany. Vascular plants. Kyiv: Fitosotziotzentr, 432 p. [In Ukrainian].

Pushkariova, N. O. (2017). Establishment of microclonal propagation methods and study of in vitro cultivation effect on biochemical properties and genetic variability of endangered Crambe species. Doctoral Dissertation for Philosophy Science (03.00.20 - Biotechnology), 155 p. [In Ukrainian].

Rais, E. (1978). Allelopathy. Moscow: Mir, 392 p. [In Russian].

Razavi, S. M., \& Nejad-Ebrahimi, S. (2009). Chemical composition, allelopatic and cytotoxic effects of essential oils of flowering tops and leaves of Crambe orientalis L. from Iran. Natural Product Research, 23(16), 492-498.

Red Book. (2019). Red Book of Ukraine. Brassicaceae. Retrieved from: https://redbook-ua.org/category/brassicaceae/

Roshchina, V. D. (1974). The exemetabolites of the arboreal plants and mechanisms of their impact on the plant cells. Thesis of the Doctoral Dissertation for Biological Sciences (03.00.12 - Plant Physiology and Biochemistry), 43 p. [In Russian].

Yurchak, L. D. (2005). The allelopathy in agrobiocenoses of the aromatic plants. Kyiv: Fitosotziotzentr, 411 p. [In Ukrainian].

N. Ya. Levchyk', D. B. Rahmetov' ${ }^{1}$ A. V. Liubinska ${ }^{1}$, N. Ye. Horbenko ${ }^{2}$

${ }^{I}$ M. M. Gryshko National botanical garden, NAS Ukraine, Kyiv, Ukraine ${ }^{2}$ Ukrainian National Forestry University, Lviv, Ukraine

\section{THE ALELOPATHIC POTENTIAL OF CRAMBE L. PLANTS (BRASSICACEAE BURNETT) AT COLLECTION OF M. M. HRYSHKO NATIONAL BOTANICAL GARDEN, NAS OF UKRAINE}

The article represents the morphological and biological characteristics of the genus Crambe L.plants, their allelopathic properties and the toxicity of the fruits and root extracts. Characteristics are given according to the literature sources. The mechanism of alylopathically active compounds action on the cellular, organism and population levels (creation of an allelopathic field) is analyzed. The article represents the comprehensive study results of the allelopathic activity of water soluble biologically active compounds of the vegetative part, seeds and rhizospheric isolates of the Crambe L. genus. Their active compounds quantitative content is in a certain dynamics during the vegetation. The plants exercise allelopathic effect on thesurrounding higher plants due to these compounds (stimulating or inhibiting), and the action force varies depending on the vegetation phases and the test objects. In the course of our study we have established that the first half of the growing season of the biologically active compounds of the above-ground masses season has essential inhibition characteristic of the plants development. During the second half of the growing season the inhibitory effect is weakened, and in some cases shows itself in a significant stimulation. We have concluded that the maximum level of inhibition by bioactive compounds of the vegetative part of the studied Crambe species occurs at an extract concentration of 1:10. The strongest stimulation by contrast is provided when the concentration of the extract is $1: 100$. We have also found that the extracts from fruits and seeds of the studied Crambe species have an exclusively inhibitory effect at the concentration of 1:10 and have a stimulating effect at the concentrations of 1:50 and 1:100. We have revealed that the biologically active compounds of the investigated plants rootstock has an inhibitory and stimulating effect on the plant growth. The nature and the action force depends on the vegetative phase and the receptor plant. The most active stimulating effect on the test plants has the soil of the $C$. steveniana, the middle stimulating effect $-C$. coctebelica, the lowest $-C$. pontica. The strategy for the survival and distribution of this genus plants in the coenosis has been formulated in this connection.

Keywords: colewort; allelopathy; extractor; test plant; inhibitor; stimulant. 